\title{
LABOR'S DEMAND FOR REAL EMPLOYMENT SECURITY
}

\section{KATHERINE POLLAK ELLICKSON}

THE spectre of the sidewalk apple-seller still looms larger than the unemployment benefit check in the minds of American workers. As compared with the nation's total unpreparedness for the depression of the early $1930 \mathrm{~s}$, it is no mean accomplishment to have 30 million workers covered by unemployment insurance today. But the basic urge of Americans is for jobs resulting from continuously high production, and there is no assurance that these will be available. Moreover, the amount of protection afforded by our employment security systems falls far short of freeing the people from want.

The Social Security Act was passed ten years ago because of a widespread, if belated, recognition that unemployment is a national problem for which the entire community must take responsibility. This represented a tremendous step forward from the earlier attitude that a man could find a job if he really wanted to and that charity, on an unplanned local basis, was the only protection needed for his family. Now, ten years later, there is determination that unemployment must be wiped out entirely, except as it inevitably occurs for short periods between jobs. The war has revealed the nature of full employment, in sharp contrast to the dark days of 1932 . MIore and more people understand that jobs for all is a practical plan for the entire community, not simply an idealistic slogan. Just as social responsibility for providing insurance against unavoidable hazards has been recognized, so is social responsibility for minimizing those hazards being accepted.

The year that ends the first decade of federal-state unemployment insurance marks also a rapidly growing interest in the use of the guaranteed annual wage to help avert the evils of unemployment. In the next decade, this interest may result in new social inventions that, will gear unemployment insurance into current plans for providing full employment and assured incomes. The demand for the guaranteed annual wage reflects labor's deep-seated desire for steady jobs with adequate earnings. A wage-earner has no real security unless he lnows he will have an opportunity to work at good pay not just this month but all year and next year and as long as he is able. A job provides an assured place in the community and conveys a sense of personal value and dignity that no form of insurance can replace. To be unemployed, even with weekly benefits for a time, means to doubt one's ability to find a job again, to feel useless and somehow lacking. Labor realizes, moreover, that adequate levels of living depend on production, so that most workers have to be turning out goods and services if those who are unemployed are to receive really adequate benefits.

$\dagger$ Assistant Director of Research, CIO. 
But labor contends equally vigorously that if people are denied the opportunity to work, they and their families must have enough income not merely for bare subsistence, but for health, decent surroundings and education, and a sound family life. Unemployment insurance should be the floor which can be relied upon for decent support if workers are temporarily unemployed during a period of high activity like the war years or if a flood of unemployment again engulfs the nation. Labor does not accept the idea that unemployment insurance should be designed merely for short-term temporary unemployment. There is no other floor to prevent wage-earners' families from being submerged in fear, hunger, and despair during depression periods. Public works have not been planned in sufficient volume to provide jobs for all who will need them. The WPA, even with all its shortcomings, no longer exists. The federal government does not have any program of its own for relief to the unemployed, and many states and counties, especially in the south, exclude employable persons from public aid. Even where relief is available it is deplorably inadequate. But in any case labor does not want to receive charity from either public or private sources. Only decent insurance benefits, received as a matter of right when neither private nor public employment is available, can be considered even a minimum form of protection in keeping with the realities of modern industrial life.

Labor's belief that every family should receive enough for a decent living, either through work or benefits, has been given tremendous support by economists who now agree that more income must be in the hands of the lower income groups if our economy is to continue operating at full productive capacity. Keynes and others have shown that oversaving results in chronic unemployment and must be offset by permitting the lower income groups, who save a smaller proportion, to receive more money. Thus, labor's desire for security coincides with the community interest.

Measured against these goals and concepts, the present unemployment compensation system is inadequate. Millions of workers are not covered at all because they work for federal, state and local governments or for small employers, or because they do not work long enough in any one state to acquire protection. Millions of others are excluded because they are in domestic, agricultural, non-profit, or maritime employment. Hundreds of thousands who think they are covered will be deprived of benefits under the harsh disqualification clauses and improper tests of suitable work which have been growing more frequent in many states as a result of experience rating.

But even those who draw benefits will receive far too little protection. Duration of 26 weeks is the maximum, and many states (19 as of June 30,1945$)$ still have not attained even a modest 20 -week period. 
The amounts provided are far below those required for a decent level of living. The most satisfactory standard minimum budget now available, developed by the Heller Committee of the University of California, requires an income of at least $\$ 2,700$ for a worker's family of four (omitting another $\$ 300$ for war bond purchases). That comes to $\$ 52$ a week for 52 weeks. The old "minimum health and decency budget" of the United States Department of Labor, as priced several years ago by the Labor Bureau of Middle Mest in various large cities, required a weekly wage of over $\$ 40 .{ }^{1}$ Yet only nine states now pay a maximum of more than $\$ 20$ a week, no matter how large the family, while thirteen states still have a $\$ 15$ or $\$ 16$ limit. Even if such benefits were paid for a full year, they would equal less than one-half of the substandard maintenance budget, and less than one-third of a decent budget. Combined with the strict limits on duration, yearly maximums are actually even lower. As of June 30,1945, the maximum that could be collected by any worker in a given benefit year in a typical state was $\$ 364.50$ (the median for all 51 states and territories). Only 14 states permitted total payments of more than $\$ 400$ in any one benefit year.

The G.I. Bill of Rights, although less generous than labor urged, gives unemployed veterans benefits of $\$ 20$ a week for a possible 52 weeks, a potential total of $\$ 1,040$, which is more than double the greatest amount provided by any state for any of its unemployed workers as of the beginning of $1945 .{ }^{2}$ But while setting a more liberal monetary standard, the G.I. law provides that a veteran may be refused benefits if he leaves "suitable work" voluntarily or without "good cause" or fails to "accept suitable work when offered him." In the definition of these terms the conditions and standards prescribed by the unemployment compensation law of the state shall apply, though appeal to the Veterans Administration is possible. ${ }^{3}$

It must be remembered, finally, that by no means all workers are entitled to the maximum benefit in their state law. In one state the average weekly benefit in 1943 was only $\$ 7$. In the fourth quarter of 1941 , the average weekly benefit for all states was $\$ 16.51$, as compared with average weekly earnings of $\$ \$ 3.90$ in the second quarter of $19 \pm 4$.

Labor attributes these inadequacies in no small degree to the exist-

1. Even the old subsistence budget of the WPA, adjusted to food buying habits and to include bonds and taxes, required a yearly income of $\$ 1,752$ or a veelily wage of $\$ 34$, according to a price survey of the Textile Workers Union in early 1914. This was admittcdly substandard. The admittedly inadequate "maintenance" budget of the WPA required $\$ 1,700$ a year or $\$ 33$ a week for a family of four when last priced by the Department of Labor, in June 1943.

2. Washington, as a result of 1945 amendments, provides the most gencrous maximum benefits, with a maximum of $\$ 25$ a week for a maximum duration of 26 veels, or a possible total of $\$ 650$ for some workers.

3. See Wilbur J. Cohen, The Federal Gocernment's Program for Es-seniecmen (1915) 238 AnNals 63, 68. 
ence of experience rating, which has permitted tax reductions based on an employer's experience with the risk of unemployment. The measures or formulas used in reducing taxes have little to do with a concern's results in stabilizing employment. Instead, the test is usually the amount of benefits paid to the concern's former workers. The theoretical 3 percent payroll tax on employers provided by the 1935 legislation now exists largely as an abstraction. Under the experience rating provisions, enacted over labor's opposition in 45 states, the tax has been drastically reduced so that the average for the country as a whole was 1.8 percent in 1944 under the state laws, as compared with the 2.7 percent that was expected to be collected in each state for financing unemployment compensation benefits. In five states the employers' average tax rate was under 1 percent in 1944. In only eight states was the 2.7 percent still in effect.

Supporters of experience rating point to the more than six billion dollars in the state unemployment insurance funds as one justification of the lower tax rates. They even argue that most state funds are adequate in view of existing benefit provisions. But this is no answer when benefit provisions are deficient. When the state laws were enacted after 1935, the protection given the workers was scaled down to the over-conservative estimates of actuaries. Instead of liberalizing benefits sufficiently, as experience has shown was possible under the existing tax, the employers in most states have received liberal financial relief through experience rating while the benefit provisions have not been made as adequate as is needed and as is financially possible. Such policies have been especially indefensible during the war period when higher taxes could most easily have been collected, when purchasing power was deliberately being curtailed through wage controls to fight inflation, and when management was as little responsible for high employment as workers will be for the postwar unemployment that will as inevitably follow.

Experience rating has re-introduced interstate competition between the 51 separate systems so that improvement of benefit provisions has been difficult. As soon as some states reduced employers' taxes through experience rating, the argument was made in other state legislatures that similar steps must be taken in order to continue to attract private business. Otherwise, it was claimed, industries would move to the more favorable states or would locate there when choosing a new site. The argument proved powerful in legislature after legislature. Even in New York, where workers' political influence is relatively great, a modified form of experience rating was adopted this year as a compromise measure. In spite of labor's opposition, the pressure on the legislators proved too strong when 44 other states had already acted to reduce employer's contributions.

Interstate competition to lower taxes operates as a brake on im- 
provements. Under any unemployment insurance system, certain employers would oppose liberal benefit provisions that mean higher taxes, in spite of the obvious benefits to the whole community that result from putting a floor under purchasing power and providing adequate protection to workers. In a democracy, the people through their elected representatives must resolve the conflicting desires of worliers and employers on such a matter. Experience rating, combined with the 51 state systems, makes it difficult for the people to understand the issues clearly. The idea of rewarding employers for stabilizing employment is superficially attractive, and the limitations and evils of the program are less readily apparent. Social security is a hard enough subject for any layman to grapple with in all its technical details, and the variations in the state laws make it very difficult to carry on effective education.

The main burden of such education falls on the unions, which operate primarily on a national basis, matching the national character of modern industry. The task of informing their field people and members about 51 state laws is tremendous. Even the CIO Department of Research and Education has had difficulty in making arailable a simple leaflet on "First Aid in Lay-Offs," including specific facts on the workers' "rights and wrongs" under the unemployment compensation laws of different states. Employers, with far larger resources, can more easily employ competently trained persons to develop supfort for their position and to lobby in all the legislatures. Unionists are inclined to believe that the confusion of the state systems is not altogether unacceptable to those who oppose a well-developed social security system.

The problem extends to administrative rules as well as legislative action. Employers have been able to devote far more attention to interpretations of whether individual workers are eligible after they have turned down an offered job or left a position without being fired. In the large number of states where employers' taxes are based on the amount of benefits drawn by their former employees, the employers have a direct interest in holding down the number of persons benefited. By disqualifying workers from receiving benefits, an employer avoids the charge on his account and therefore stands to pay a lower tax. Some companies have filed appeals against allowances of benefits in a large proportion of claims of former employees. Often, as the date of hearing approaches, the company has withdrawn the appeal with the result that its action serves only to burden administration and delay payment of benefits. While management has been active in seeling to influence administrative rulings on eligibility, labor has often found that its resources for this purpose were more limited than its desires.

The severe disqualifying provisions now in effect in many states are largely the fruit of experience rating. Early in 1945, 19 states canceled all or some of the wage credits of workers for voluntarily leaving a job 
without "good cause." Twenty-one canceled all or some of the wage credits for refusal of "suitable work." Interpretations of such phrases as "suitable work" or "good cause" are often very harsh from the wage-earner's point of view. Hundreds of thousands of workers will, as a result, lose all or part of their benefit rights during reconversion. ${ }^{4}$

As labor sees it, a uniform national system of unemployment insurance is required, to provide uniform taxes and benefits regardless of where a worker lives or an employer carries on business. Markets for business and labor are now nation-wide. State boundaries, established before modern transportation methods developed, cut across present lines of economic movement. People travel by the millions from state to state, both as children and as adults, so that the entire nation suffers if one area is not provided with adequate levels of living. In the postwar period especially, a unified employment service is required to prevent unnecessary migration in search of work and to enable employers to fill their needs promptly. Since unemployment compensation must be closely integrated with the employment service, this provides an additional sound reason for a national system of unemployment insurance.

Necessary adaptation to local conditions can be provided by formulas which relate benefits to earnings and thus automatically adjust to differences in wage levels. The increased use of advisory committees to watch local administration can minimize bureaucratic evils, which in practice are apt to be worse under a federal-state than under a purely federal system.

Some persons point to the improving amendments that have been passed in the states as proof that even $\mathbf{5 1}$ different systems can be made to function. However, the increasingly severe qualifying provisions must be weighed against the shorter waiting periods, the coverage of smaller employers, and the somewhat longer duration provisions. Increases in benefit amounts must similarly be evaluated in terms of the increase in the cost of living which has equalled over 30 percent, or at least as much as the rise in level of maximum benefits. It must be remembered, moreover, that fear of federalization was used by many groups, such as the Council of State Governments, as an argument for improving the state laws.

Labor's dissatisfaction is expressed in the demand for the Wagner-

4. For discussions of disqualification provisions see articles on Eligibility and Disqualification, pages 117-204 supra; Clague and Reticker, Trends in Disqualification from Benefits under State Unemployment Compensation Laws, Social Security Bulletin, Jan. 1944, pp. 12-23, and Exhibits VII(a) and (b) in statement of Senator Harley M. Kilgore, before the Senate Committee on Finance, on S. 1274, Aug. 29, 1945.

As indicated earlier in the text, the G. I. Bill of Rights does not exempt veterans from these disqualifying provisions, although a special appeal to the Veterans Administration is made possible. 
Murray-Dingell bill, which was introduced in Congress with labor's support in, June 1943, and re-introduced with some changes in May, 1945 , no hearings having been held in the two-year interval.5 Because of labor's fear of widespread unemployment during reconversion, support has been given to emergency federal unemployment insurance to cover many additional groups of workers and to supplement inadequate state benefits. Labor vainly urged passage of such legislation in connection with other reconversion legislation in 1941 but derived new hope from President Truman's request in May 1945 that Congress provide federal benefits up to a maximum of at least $\$ 25$ a week for as much as 26 weeks for all war workers and federal employees. As reconversion unemployment grows and the inadequacies of the state systems are borne home in benefits denied and widespread suffering, the demand for better legislation will undoubtedly increase.

At the same time that labor presses its case for an adequate national system of unemployment compensation to provide the necessary floor of protection for persons who cannot find jobs, the basic drive for full employment will presumably lead to new suggestions for adapting the system to employment stabilization needs. The demand for the guaranteed annual wage has already led to the appointment of a Presidential Subcommittee on Guaranteed Wage Plans, subsidiary to the Advisory Board of the Director of Mar Mobilization and Reconversion. It is expected that a comprehensive report will result, dealing with variations in employment and unemployment and exploring the possibilities of improving industrial practices so that a greater degree of stability can be achieved. An increasing number of unions are seeking to incorporate guaranteed annual wage clauses in their agreements, and more and more employers are manifesting interest in this proposal, which they feel would help to cut down turnover, reduce overhead costs, and stimulate workers to increase output as fears of unemployment dwindle. Research projects and actual experimentation alike, combined with popular resentment when unemployment grows, can be expected to lead to ever greater interest in guaranteed wage plans and employment stabilization.

Labor, in rejecting experience rating as an integral part of unemployment compensation laws, does not necessarily oppose the use of taxes as an incentive to employers to maintain steady work. There are other forms of taxation besides the payroll tax for social security which could theoretically be adjusted to reward and punish-for example, the corporate income tax. If such devices are to be used, a number of difficult problems must be explored. Under experience rating, the formulas used for judging merit have had only a very rough relation-

5. For CIO position and analysis of the bill see For tre Natro:i's Secuntry (CIO Dep't of Research and Education, 1913, revised 1945). 
ship to employers' efforts or power to reduce unemployment. There is also the problem of stimulating stabilization at high rather than low levels. Analysis of results under present unemployment compensation laws will be of interest as it provides light on these and other problems of employment stabilization.

In its program to maintain $60,000,000$ jobs, however, labor does not place any particular emphasis at the present time on the use of tax incentives based on employment experience to influence individual employers to stabilize their operations. Labor's two main approaches are, first, the establishment by the government of a general framework for economic activity conducive to the achievement of full employment; and second, the extension of guaranteed wage plans through collective bargaining.

As a means of providing the proper general framework, support is given to legislation such as the Murray "full employment" bill, which calls for the preparation of a national production-employment budget to relate fiscal policy, including public works, to gross national product, and when necessary provides for offsetting inadequate business activity. Other appropriate measures are considered to be national planning for full use of resources, with councils of labor, management, agriculture and government in the major industries; vigorous steps against monopolies and restrictive practices; and higher purchasing power resulting from good wage rates, at least a $65 \mathrm{c}$ minimum hourly rate, and other methods of raising incomes at the lower end of the scale. ${ }^{0}$

The guaranteed annual wage approach brings the goal of $60,000,000$ jobs or full employment down to the everyday practical realities with which workers and local unions are confronted. A worker knows his family has to eat 365 days a year, and he knows that during the war there have been plenty of jobs. He wants to be sure of steady income and plenty of opportunity to work. He readily understands that the guaranteed annual wage would give him these things, whereas discussions of fiscal policy are far removed from his experience. American unions have always emphasized the collective bargaining approach more than their European brothers, and labor's experience with the government during the war has not overcome doubts as to the desirability of relying primarily on government action. Contrary to the impression some people have gained, labor is not asking for enactment of legislation to enforce the guaranteed annual wage. The objective is to stimulate sincere efforts by employers to stabilize their businesses to the point that the request can be incorporated in collective bargaining agreements. In this way, provisions can be adapted to the particular

6. For a recent statement on these matters by the CIO Reconversion Comminittee sce its pamphlet RE-EMrLoyment, which supplements the earlier report of the CIO Postwar Planning Committee, As WE Wis. 
situation. It is recognized, however, that legislation will be needed to help achieve full employment and perhaps more specifically to facilitate agreements on stable employment.

While labor's own views on guaranteed wage plans will undoubtedly be developed in greater detail as experience grows, certain generalizations as to labor's objectives are already possible. The goal is for steady employment at good incomes, not just this year or next year, but every year. Although the slogan is in terms of income, the objective is employment. Labor believes that if wages become a fixed cost, like rent and interest, employers will devise methods of meeting this cost without loss. In other words, they will see to it that there is work to be done. But if employment is not forthcoming, then labor feels it should receive income just the same. Compulsory idleness with payments is better than compulsory idleness without payments.

If the individual employer cannot regularize his activities alone, then groups of employers or entire industries or even inter-industry groups can apply their ingenuity to stabilizing markets, production, and jobs. Workmen's compensation, the 8 -hour day, the 40-hour week and the Fair Labor Standards Act were all condemned initially by most employers as being impractical and disastrous to business. Management's ingenuity was sufficiently great to make necessary adjustments, and the measures proved beneficial, as labor had contended.

The demand for the guaranteed annual wage is a challenge to business to use similar ingenuity to meet the nation's basic needs. In the past, not the employers but the workers' families and the community have had to bear the costs of fluctuations in employment. This situation has become increasingly intolerable. Refusal of employers to accept responsibility in this field would lead to increasing doubt as to whether private enterprise can direct economic activity for the maximum welfare of the people. Conservative spokesmen keep saying that business will do well enough if government will keep its hands off. Labor supports private enterprise, but is asking for some guarantee that business will deliver on its promises of full production. "Just write those guarantees into our contracts in the form of guaranteed wage plans," the unions say, "rather than expecting us to talie your word with no protection for our people in case you can't deliver."

An encouraging number of employers realize their responsibilities in this regard and are as interested as labor in the studies of the Presidential Subcommittee on Guaranteed Wage Plans, but some employers continue to brand the whole approach as impractical. The steel companies argued, in answer to the union's demand, that they could not control the fluctuations in that industry because they were dependent upon orders from automobile producers, railroad equipment manufacturers, construction companies and other customers. Labor's answer 
is that in many cases the individual employer or industry-wide associations of employers can do much to correct the evils. Where more fundamental and comprehensive action is required, labor would like to see employers give support to national policies which would further stabilization. Thus, the collective bargaining approach to full employment supplements efforts to enact the Murray-Wagner "full employment" bill.

If employers accept guaranteed wage plans and shoulder responsibility for the risks of unemployment, they may themselves seek a new form of insurance to help them meet this obligation. In the case of work accidents, the employer had definite responsibility and liability to recompense workers under the common law before the workers' compensation laws were passed. These provided not only greater protection for workers but insurance of the employers themselves. Perhaps in the case of unemployment, the assumption of employer responsibility will follow the enactment of insurance for workers and will lead to new forms resulting from the employer's desire to reinsure the risk he has assumed.

While it is perhaps premature to speculate as to the ways in which the guaranteed wage demand will affect our unemployment insurance system, it is obvious that a new type of approach to assuring income and jobs may bring substantial amendments. Already, in bargaining negotiations, the unions have been told by employers that in effect their desire means the establishment of a private system of unemployment insurance guaranteeing payments for a given number of weeks even if jobs are lacking. It may be that when employers accept this type of responsibility, they will simultaneously seek some form of national fund to help them meet the obligation.

From labor's point of view, it is no answer to say that unemployment insurance fills the need, for unemployment insurance does not carry with it attachment to a job over a period of time. Moreover, present benefits are necessarily less than previous earnings, which for many workers are far from substantial even in good times and fall far below subsistence levels in bad times. The inadequacies of the present unemployment benefit provisions reinforce labor's impatience with considering them a substitute for employer responsibility.

This does not mean that guaranteed annual wages are intended to eliminate unemployment insurance, which will be required for workers while they are seeking new jobs. Individuals should have more, not less, opportunity for betterment, and technological changes will always necessitate some adjustments.

While widespread labor demand for a given objective does not necessarily result in fulfilment, the pressures are strong and can be expected to grow in proportion to the failure of other approaches. It was no accident that 1935 marked not only the passage of the Social Security 
Act but the birth of the CIO and the enactment of the National Labor Relations Act. All arose in response to the deep-seated desire of labor for security fostered by the terrible experiences in the depression years. These had proved beyond all doubt that the individual worker was helpless under modern industrial conditions without organization and legislation to protect him. The New Deal was the result, and by 1935 sufficient experience had been acquired to permit formulations of concrete legislation to succeed stop-gap experimental measures. The formation of the $\mathrm{CIO}$, and its success in creating stable unions for the first time in the modern mass production industries such as steel, autos, and electrical manufacturing, meant that the semi-skilled and unskilled workers had gained powerful machinery for expressing and furthering their needs. These groups, even more than the skilled craftsmen, find it impossible to protect themselves against the hazards of unemployment. The CIO, accordingly, regards adequate unemployment insurance as a definite social responsibility.

Since 1935 union membership has more than tripled, so that it stands today at over $14,000,000$. Unionism itself is the most basic form of security for the wage-earner since it protects his right to a job if one is available and helps him to secure legislation for better employment or more adequate social security. Continued union strength will undoubtedly, under reconversion conditions, mean an ever-broadening social security program. Only restriction or repression of unions can interfere for long with continued democratic progress towards the goal of jobs for all, combined with a truly adequate system of social insurance. 


\section{THE YALE LAW JOURNAL}

EDITORIAL BOARD

JoRgE R. HAYZuS

Editor-in-Chief

JoHN C. JAQUA, JR.

Comment Editor

Donald F. KEefE

Comment Edilor

Samuel D. Mercer

Note Editor

Philip B. Brown

David C. GoRdon

Editors in Charge of This Issue

JOEN P. FURAMAN

DAVID C. GoRdon

F. Aley Allan

Subscription price $\$ 4.50$ per year

$\$ 1.25$ per number

Canadian subscription price $\$ 5.00$ per year; Foreign, $\$ 5.25$ per year

Yale Law Journal Company, Inc., Box 4orA, Yale Station, New Haven, Conn.

The Social Security Act closes the first decade of its existence in the year that marks the end of World War II. With the return of millions of discharged veterans to the domestic labor market, the possibility of widespread unemployment draws attention once again to the problem at which the Social Security system was originally directed. It also raises the question of how effective a contribution the Act may be expected to make at the present time in the gradual process of national economic readjustment.

Under these circumstances it has seemed a worthwhile public service to publish an integrated series of articles discussing the development of unemployment compensation during the past ten years, evaluating the program as now administered, and presenting to the legal profession a survey of certain provisions of the various state statutes governing liability for taxation and eligibility for benefits as they have been interpreted by the courts.

The editors of this special issue wish to express their appreciation to the many federal and state officials, representatives of labor and industry, and other students of social security who, whether able or not to contribute to the issue as authors, assisted immeasurably in its preparation by their advice and encouragement. 


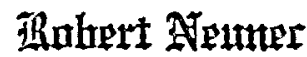

The Editorial Board of The Yale Law Journal, jointing in tribute to the memory of a distinguished continental lanyer and former lecturer at the Yale Law School, publish the following resolution passed by the Yale Law Faculty on December 6, I945.

REsolved, that the Yale Law Faculty record its sorrow at the death of Robert Neuner, refugee from Nazi barbarism, who died a casualty of war in the cause of freedom.

We were honored, in 1939, to take in Robert Neuner, brilliant young scholar of law, and courageous spokesman in Europe of the values of democracy. An effective teacher and a recognized scholar of law, Mr. Neuner had become a leader among those who struggled to preserve civilization against the Nazi challenge. His fighting faith made him a marked man when the Germans occupied Czechoslovakia in 1939. He had to flee for his life.

At Yale he accomplished the difficult feat of re-education and transition, and gave us at the same time the advantage of his ability, his point of view, and his experience. He became a productive member of the American legal community. After three years of useful work as Lecturer in Law (with the rank of Associate Professor) at Yale, he went to Washington, where he served the government first in the Federal Communications Commission, and finally on the War Crimes Commission. In each case his worls was marked by distinction and creativeness. Incisive and analytical, his contributions won increasing recognition. While serving in Germany, however, he contracted the illness from which he died, at the Walter Reed Hospital in Washington, on November 23, 1945.

A man of moral force and moral courage, Robert Neuner was more than a good scholar. He represented the great tradition of the liberal universities, the tradition of being willing to fight for justice as well as to preach it. He will long be remembered. 
